\title{
REMITTING OF A CASE TO THE TRIAL COURT AND THE DUTY TO TAKE STEPS TO OBTAIN EVIDENCE TO DETERMINE THE EXISTENCE OF SUBSTANTIAL AND COMPELLING CIRCUMSTANCES
}

\author{
Calvin v The State (962/2013) \\ [2014] ZASCA 145 (26 September 2014)*
}

Introduction

It has been a while since the minimum-sentencing legislation introduced a new approach to sentencing in the South African courts. After the initial resistance and considerable diversity in the different courts' approach to the legislation, it can now been said that the courts have given adequate clarity to the sentencing regime and how it should be approached. In $S v$ Malgas (2001 (2) SA 1222 (SCA)), the court outlined the principles and the procedure that are appropriate in dealing with this sentencing regime. In $S \mathrm{~V}$ Dodo (2001 (3) SA 382 (CC)), the Constitutional Court solidified the approach adopted in Malgas and, since then, there appears to be clarity regarding the sentencing approach. In sum, the courts are obliged to impose the specified minimum sentences unless there are substantial and compelling circumstances. In the absence of such substantial and compelling circumstances, the court has no option but to impose the prescribed minimum sentence. Schoeman AJA, in Calvin $v$ The State ((962/2013) [2014] ZASCA 145) - the focus of this case note - aptly summarised the approach as follows:

"The minimum sentence has been set as a benchmark prescribing the sentence to be ordinarily imposed for specific crimes and should not be departed from for superficial reasons" (par 8).

However, there are still situations in which the courts impose minimum sentences without adequately inquiring into the existence or otherwise of substantial and compelling circumstances. Such was the case in Calvin v The State (supra), where the appeal court found that the trial court had misdirected itself in not taking steps to obtain evidence which would enable it to make a proper assessment as to whether substantial and compelling circumstances existed. This note deals with the importance and necessity of such proper assessment for sentencing purposes and highlights that,

\footnotetext{
I thank Joseph Sedumedi and Simon Rasikhalela for their useful comments in our discussion of this judgment in the preparation of this case note. I also thank Kokeletso Maforah for her incisive and pertinent comments on the draft of this case note. They all shaped the case note, but all the errors in fact, law and analysis are solely mine.
} 
despite the provision in section 274(1) of the Criminal Procedure Act (51 of 1977) bestowing discretion on the trial court, the Supreme Court of Appeal has proclaimed such assessment as a duty, as will be argued later herein.

Further, it is argued that the interests of justice would have been better served if the case had been referred to the trial court for a proper sentencing process to take place. What is questioned, in a nutshell, is the decision by the appeal court to assume the role of the sentencing court in the circumstances of this case.

\section{Factual background}

The appellant had been convicted of rape and sentenced to life imprisonment by the Limpopo High Court, Thohoyandou. The rape had occurred on 10 March 2005. The accused had dragged the 6-year-old victim into an orchard and raped her, which rape was interrupted when a passerby was alerted to the activity by the victim's screams. Having been noticed, the appellant stopped raping the victim and ran away (par 2).

He appeared before court on a charge of rape after handing himself over on learning that the police were looking for him. In terms of section 51 of the Criminal Law Amendment Act (105 of 1997), this charge invited the application of the minimum sentence upon conviction because the victim was under the age of sixteen years (par 1). He pleaded not guilty to the charge and was subsequently convicted of rape. He did not testify during the trial, including during the sentencing process, with the result that all the court had to take into consideration were statements from the bar by his legal representative (par 4).

\section{On appeal}

The appeal, against sentence only, was before the Supreme Court of Appeal with the leave of the trial court. The first ground of appeal was that "the sentence of life imprisonment is shockingly inappropriate and it induces a sense of shock" (par 3). The second ground was that "the court below should have found that there were substantial and compelling circumstances present that justified a deviation from the minimum sentence" (par 3).

Schoeman AJA, with Cachalia and Willis JJA concurring, found that the trial court had misdirected itself on two main grounds. First, it did not consider all the circumstances of the accused in sentencing even though such had been put on record by the accused's legal representative. This, the court held, did not line with the court's duty to consider all the factors in deciding whether to impose a minimum sentence on the accused or not. So, there was no evidence on record - in the judgment from the trial court - that the court inquired into whether or not there were compelling and substantial circumstances in the case.

Secondly, the court did not have a pre-sentence report which could, among others, have given the court a picture of what the impact of the crime was on the victim. The court was emphatic that it is the trial court's duty to 
get evidence that would enable it to consider a proper sentence. Schoeman AJA, stated:

"If the defence and prosecution fail to adduce such evidence, the court is obliged to take steps to receive such evidence in order to determine whether there are substantial and compelling circumstances" (par 7).

Having found that the trial court had misdirected itself by, first, not considering all the relevant factors regarding the offence and, secondly, not having taken steps to obtain the evidence necessary to enable it to assess whether substantial and compelling circumstances were present in the case, the appeal succeeded. The court, in this regard, found: "It is clear that the trial court failed to approach sentence in this way and thereby misdirected itself" (par 9).

The next level of inquiry was whether the case should be referred back to the high court for the sentencing process to start de novo. The court appraised the circumstances surrounding the case in order to determine whether in the circumstances it would be in the interests of justice to refer the matter for sentencing. The court mentioned that this would ordinarily be the most appropriate step but not in this case. Three reasons were advanced for this approach. First, given the passage of time in the case, it would not be feasible to obtain a pre-sentence report. It was 9 years after the crime had been committed when the appeal court handed down its judgment. Secondly, an impact-assessment statement of the victim would not be that useful also because of the time that has passed between the commission of the crime and the appeal proceedings. Thirdly, the judge who tried and sentenced the appellant had passed away, but the court hastened to also mention that this was not necessarily preventing the case from being sent back to the court for sentencing.

The court, as result, used the information available to it to decide an appropriate sentence. It took into account the youthfulness of the appellant who was a first offender; the seriousness of the crime and its impact on the victim and the time spent by appellant before trial. After considering the information at its disposal, the court found that life imprisonment was disproportionally harsh in this case. Consequently, the appeal was upheld and the sentence of life imprisonment substituted with 20 years' imprisonment. The sentence was antedated to 05 October 2005, the date on which the trial court sentenced the appellant.

\section{Discussion}

It is submitted that this decision, further to affirming the previous decisions in the appropriate approach to minimum sentences, contributes to the sentencing regime in two significant ways. First, it makes it a duty on the part of the court to take steps to obtain the evidence necessary for sentencing (par 7). Secondly, it confirms the need to remit a case to the trial court for sentencing to take place afresh, but subjects that approach to the circumstances of each case with the guiding principle being what best serves the interests of justice. The note turns to deal with the two contributions in their order. 


\section{Trial court's duty to obtain evidence}

Section 274(1) of the Criminal Procedure Act provides that:

"a court may, before passing sentence, receive such evidence as it thinks fit in order to inform itself as to the proper sentence to be passed".

It is significant that the section employs the word "may" and not "must" as this shows that the court is allowed to receive the evidence but not compelled to do so. However, Schoeman AJA, stated, in this case, that "the court is obliged to take steps to receive such evidence in order to determine whether there are substantial and compelling circumstances present" (par 7). There is an immediate departure from the legislative provision in the judge's wording. It is, according to the judgment, not a discretion that the court exercises but an obligation on the part of the court during sentencing proceedings. This obligation is supported by the precedent that the judge refers to. Referring to S v Olivier (2010 (2) SACR 178 (SCA)), she stated:

"This court has in the past stressed the importance of placing as much evidence before the court as possible in respect of the perpetrator, the victim and the circumstances surrounding the commission of the offence" (par 7).

Terblanche ("The Sentence" in Joubert (ed) Criminal Procedure Handbook 11ed (2014) 330-331) supports this approach. He states:

"However, in the final analysis it is the court that has to impose the sentence. It has the discretion; a discretion which cannot be exercised properly unless all the information necessary to make such an important decision is at the disposal of the court."

It is submitted that this decision has reshaped the approach of the court to sentencing in making it a duty on the court's part to take steps in order to get the necessary evidence for sentencing purposes. Terblanche (in Joubert (ed) Criminal Procedure Handbook 329) observed that, "tradition seems to require the state and the accused to supply this information". He then points out that section $274(1)$ empowers the court to receive the evidence that enables it to exercise its discretion (Terblanche in Joubert (ed) Criminal Procedure Handbook 329). It is clear that Terblanche's perception is in line with that of the section and, equally, clear that they are both not as peremptory as phrased by Schoeman AJA. The judge does not state whether this approach is applicable to all sentencing procedures or only in respect of cases where the minimum-sentences legislation is applicable. There are two possible interpretations of this finding. The one could be that, given that this case dealt with a case to which the minimum-sentence legislation is applicable, this duty on the part of the presiding officer would be restricted to such situations. The other interpretation, which is equally cogent, is that this does not necessarily restrict the duty to cases where minimum sentences come into play but apply to all cases. It is submitted that the second interpretation can be supported in that the enabling section (s 274(1)) does not differentiate between cases in terms of their seriousness for the purposes of gathering information for sentencing purposes. 


\section{Remitting of a case to the trial court}

Section 275 of the Criminal Procedure Act (51 of 1977) enables remission of a case to the trial court even if the judge who presided cannot attend to the case by providing:

"(2) Whenever -

(a) a judge is required to sentence an accused convicted by him or her of any offence; or

(b) any matter is remitted on appeal or otherwise to the judge who presided at the trial of an accused, and that judge is for any reason not available, any other judge of the provincial or local division concerned may, after consideration of the evidence recorded and in the presence of the accused, sentence the accused or, as the case may be, take such other steps as the former judge could lawfully have taken in the proceedings in question if he or she had been available."

The court decided to consider an appropriate sentence itself instead of referring the matter to the trial court. As stated above, there were three reasons for this. These reasons seem problematic. It is difficult to see how the court, first, arrived at a conclusion that a passage of time would make it infeasible to get a pre-sentence report, secondly, how it had arrived at the conclusion that an impact-assessment report would not give an accurate picture.

Regarding the pre-sentence report, the court said:

"Due to the fact that the appellant's case was finalised nine years ago, it would not be feasible to obtain a pre-sentence report at this time."

It was not explained as to what made the obtaining of the report not feasible. The Oxford Dictionary (http://www.oxforddictionaries.com/definition/ english/feasible, (accessed 2014-11-03)) defines the word "feasible" as "possible and practical to do easily or conveniently". In that sense the court, therefore, was not referring to the value that the report could bring to the process of determining sentence but the practical hurdles that getting it would entail. This seems problematic. First, it was not for the court, without trying, to conclude on the feasibility of obtaining the pre-sentence report. It would have been a lot more understandable, it is submitted, for the sentencing court to be the one that decided that fact. Secondly, given the usual contents of a pre-sentence report, the court's reasoning becomes intriguing. As Terblanche (Guide to Sentencing in South Africa 2ed (2007) 105) observed,

"[most] pre-sentence reports deal mainly with the offender...They often attempt to explain why the offender committed the particular crime and include suggestions on sentences that may be useful in rectifying any problems".

It could well be that the intrigue comes from the court's lack of elaboration on the infeasibility of obtaining the said report and what role exactly the lapse in time contributes to that decision. That said, and accepting Terblanche's observation as correct, time does not seem to be a deciding factor because the information could still be sourced. 
Coming to the impact statement, the court stated: "Similarly an impact study into the circumstances of the complainant might also not render an accurate reflection of her position" (par 12). This calls for a consideration of what an impact statement is and what it contains or should contain. There are a number of definitions for this concept, but the one by the South African Law Reform Commission, quoted by Muller and Van der Merwe ("Recognising the Victim in the Sentencing Phase: The Use of Victim Impact Statements in Court" 200622 SAJHR 650) is the most comprehensive and goes as follows:

"The victim impact statement is a statement made by a victim and addressed to the presiding officer to be considered in the sentencing decisions. The victim impact statement consists of a description of harm, in terms of the physical, psychological, social and economic effect that the crime had, and will have in future, on the victim. Sometimes this statement may include the victim's statement of opinion on his feelings about the crime, the offender and the sentence that he feels is appropriate."

The court's reasoning here was not that it would not be feasible to obtain an impact statement but that it "might also not render an accurate reflection of her position" (par 12). Judged against the above definition which - it must be stated - covers many other definitions available, it is difficult to see how the judge's inclusion of the accuracy of its reflection could be justified. In the absence of information to the effect that the victim is not available for any reason, for example death, she can still be interviewed and observed for the purposes of an impact statement. Ironically, the converse to the court's reasoning may just be even the more acceptable one. In other words, is it not possible that her position and how she is coping could be reflected better at this stage than could have been nine years before, especially in respect of the long-term effect of the crime on her?

\section{$5 \quad$ Concluding remarks}

This judgment, as did many others before it, makes it clear that a sentencing court cannot pass a minimum sentence without properly enquiring into the existence or otherwise of substantial and compelling circumstances. In equal measure, it emphasises that the trial court cannot just ignore a minimum sentence specified for a particular offence. The court phrases it as a duty of the sentencing court to undertake such an inquiry. In sum, where an accused has been convicted of a crime for which a minimum sentence has been prescribed, the court must inquire into the existence or otherwise of the substantial and compelling circumstances.

It can also be deduced from this judgment that, for a proper inquiry to take place, the court should have all the necessary evidence. That is, the evidence without which the court cannot properly make an assessment. In the absence of such evidence, for example where the prosecution and the defence have not provided it, the court has to take it upon itself to get the evidence. In Schoeman AJA's words, the "court is obliged to take steps to receive such evidence ..." (par 7 ).

Similarly, the judgment shows the significance of properly considering the circumstances of the accused, the seriousness of the offence and the 
interests of society. It cannot be a superficial one and it has to be reflected in the sentencing judgment that the sentencing court had taken all the circumstances into consideration. In this case, for instance, the appeal court took issue with the fact that the judgment did not reflect that the court had taken the relevant circumstances of the accused into account (par 10).

However, in the absence of the information necessary for a court to pass an appropriate sentence, it becomes a bit difficult to justify how the court arrived at the sentence of 20 years' imprisonment as it did. Is this, perhaps, the reason that is brought about by the appeal court's factoring in of the mitigating factors that the appellant's legal representative had provided during the sentencing in the court a quo and which were not considered by the presiding officer? Those facts are: "the appellant had just turned twenty when the crime was committed; he suffers from asthma; he has no relevant previous convictions and should therefore be considered a first offender; and he had been in custody as an awaiting trial prisoner for close on seven months before the trial commenced" (par 10). This is not immediately apparent if these factors account for the court's sway away from the prescribed minimum sentence because the judgment does not elaborate on this.

This comes to the core of the problem: there do not seem to be valid reasons that persuaded the court that it was in the interests of justice that the sentencing be dealt with by the appeal court instead of it being remitted to the trial court for sentencing. Above in this note, each of the reasons has been evaluated for adequacy in justifying the decision of the court not to remit the case but, for the argument and questions submitted, it appears that it would have served the interests of justice better had the court so remitted the case.

Boyane Tshehla

North-West University, Mafikeng 